\title{
Are French Teachers Passionate About Their Profession?
}

\author{
$1^{\text {st }}$ Salman Al Farisi \\ Linguistics Department Faculty of \\ Humanities \\ Universitas Indonesia \\ Depok, Indonesia \\ sal.alfarisi94@gmail.com
}

\author{
$2^{\text {nd }}$ Sisilia Setiawati Halimi* \\ Linguistics Departement \\ Faculty of Humanities \\ Universitas Indonesia \\ Depok, Indonesia \\ sshalimi@gmail.com
}

\begin{abstract}
This study discusses the passion exhibited by instructors teaching French as a foreign language in high schools in Jakarta, Bogor, Depok, Tangerang, and Bekasi (Jabodetabek). In the domain of psychology, passion is deemed to be the pivotal factor for successful classroom learning. Passion is closely correlated with motivation and the two attributes influence each other. However, the learning of French is not accorded due importance in the school curriculum and students are not adequately motivated to learn the language. The quality of French learning in schools is thus often below par. This study aims to identify the number of French teachers throughout the Jabodetabek area who display passion in their teaching practices and to describe their classroom pedagogies. It further intends to elucidate the factors that influence the passion and motivation of French instructors in high schools. This combined-method research initiative obtained data from 37 French teachers through questionnaires, self-reflection sheets, and semi-structured interviews. The collected data were subsequently processed using descriptive quantitative analysis and an independent samples t-test. The results did not identify the attribute of passion in any of the examined French teachers. However, three of the instructors came close to displaying all the qualities of teachers who are passionate about their profession. Unfortunately, these three instructors could not demonstrate learning effectiveness in their classrooms. Therefore, the investigation leads to the conclusion that there is a dire need for French teachers who are passionate about their work. The outcomes of this study also indicate several factors that influence the passion for teaching. Educational institutions must inculcate, develop, maintain, and integrate the characteristic of passion for the profession into the teacher education curriculum.
\end{abstract}

Keywords—passion, motivation, French teaching as a foreign language

\section{Introduction}

Passion is an important factor in the successful execution of any profession. Day [1] defines passion as a driving or motivational force that emanates from heartfelt determination. Thus, a passionate person works happily and with love. When people like performing their job-related duties, they tend to try all means to perfect the results of their work. In the context of education, especially, a lack of passion in the teacher renders all pedagogies useless [2], [3] and teaching becomes an unattractive, boring, and increasingly frustrating activity [4]. Passion in teachers has been identified as the foundation of effective learning [2] and it is the pivotal factor determining successful learning outcomes in students. Therefore, it is extremely necessary for researchers to increase awareness of passion in the teaching profession, which is the general objective of this research. It is vital to keep in mind that the effectiveness of classroom learning depends on the level of motivation evinced by an instructor which, in turn, is intimately tethered to the passion the teacher feels. Kyriacou \& Benmansour's study [5] describes three types of motivation to teach: altruistic, intrinsic, and extrinsic. Instructors who are altruistically motivated focus full attention on their students. Teachers who are intrinsically motivated attend to the increase of their own competence. Educators who are extrinsically motivated are more inclined to concentrate on ancillary benefits that are not directly related to their teaching activities, for example, long vacations, wages, or employment status.

Unfortunately, many researchers are too focused on the learning motivation of students, so teaching motivation is generally ignored and has not received due scholarly attention. In fact, according to Dornyei [6], efforts to transform the classroom into an interesting and exciting environment must begin with teachers. Dewaele [7] has expressed a similar viewpoint, asserting that thus far, teachers have been seen as machines, and their personal and emotional experiences have not been examined. Recent scholarship has thus indicated that it is not enough for teachers to be equipped with adequate technical knowledge (hard skills); they must also imbibe strong non-technical aptitude (soft skills), especially elevated levels of passion and teaching motivation. According to Barnes [8], beginner teachers of English tend to evince altruistic and intrinsic motivation types, articulating reasons such as love for the subject they teach, the urgent need for teachers and students to be proficient in English, and their desire to help students succeed. Thus, Barnes concluded that many English instructors feel passionate about teaching. It may be concluded that passionate teachers feel altruistic and intrinsic motivation, a view that is aligned to Day's [1] assertion that the passion for teaching is not just an intellectual and emotional involvement with students, colleagues, and parents (altruistic), but also involves oneself through reflective learning and the renewal of teaching goals and practices within the classroom (intrinsic). A similar perspective is articulated by Rampa [9], who has claimed that teachers with passion possess the characteristics of enthusiasm, intellectual emotion, emotional energy, and commitment. Such educators believe that they can change learning activities and outcomes for the better by relying on their intelligence and care. This combination of intellectual and emotional abilities produces the highest quality of learning and is closely related to the present paper's definition of the passion for teaching. 
Serin's [2] intensive inquiry into the topic posits that both learning and teaching effectiveness emanate from passion. It is thus vital to understand the indicators that can measure the effectiveness of learning. Slavin [10] postulates four such markers: the quality of learning, the appropriate level of learning, incentives, and time. Suprayekti [11], as cited by Kunandar [12], postulates five indicators of learning effectiveness: classroom management, use of time, mastery of the material, use of methods, and mastery of learning media. It may hence be concluded that learning can be said to be effective if the teachers attend to the didactic and psychological aspects of their students. This definition was adapted by Jannah [13] in a learning evaluation questionnaire administered to students to examine their learning effectiveness. In the context of language learning, an effective language teacher must exhibit competent and accurate teaching and language skills in terms of grammar, vocabulary, and pronunciation [14]. Thus learning effectiveness may be gauged from the way teachers fulfill their tasks and impart the requisite information to their students. Farrell and Richards [15] formulated this notion into aspects of teaching that were further developed and detailed by Richards, Conway, Roskvist, and Harvey [16]. The full list of language teaching aspects includes the ability to exploit teaching materials (the Internet, magazines, books, etc.); competent and accurate linguistic skills in terms of daily vocabulary, structure, and language; the wherewithal to provide appropriate corrective feedback; the skill to impart instruction in the target language; the facility to appropriately explain the vocabulary and structure of the learning material; and the capacity to offer rich language inputs. The last aspect of rich language inputs encompasses features such as the use of the target language (suitable speaking speed, adequate repetition, etc.), long and complex speech patterns with appropriate difficulty levels, the proficiency to improvise, and the appropriate use of humor. These aspects will be utilized for the present study's second component of administering self-reflection sheets to teachers on their teaching practices during their French language classes.

In general, the student demand for English as a second language exceeds the call for learning French because English is perceived as more prestigious and necessary for numerous activities. Almost all companies or agencies now require job applicants to know a foreign language, at least English. Therefore, it is natural that many highly motivated students flock to study English. However, French is relegated by the 2013 curriculum to the mere position of an optional foreign language /specialization if a student does not take a language major in high school. In addition, the teaching hours assigned to French classes have been reduced from the previous curriculum [17]. It was thus hypothesized that high school teachers and students in Indonesia do not feel the urgency to teach or learn French and the student motivation and teacher quality for the instruction of this language is consequently negatively influenced [18]. To test this hypothesis, the present study sought to identify the number of passionate French language teachers in high schools throughout the Jabodetabek area. In addition, the present investigation also attempted to elucidate the manner in which the passion these teachers felt affected their teaching practices. The effects of passion were scrutinized both from the perspective of teachers and students, and the factors that influenced this characteristic were illuminated. According to Soltis [4], passion can be developed, strengthened, and taught. In contrast to previous studies that have provided data based only on questionnaires [8], [5], [9], [2], this study produced a more empirical study of passion in the practice of teaching foreign languages, especially French, by applying the triangulation method. The results of this study are expected to extend insights on issues that must be considered to foster and maintain the passion teachers feel for their profession. The study further explicates the importance of the influence exerted by the attribute of passion on the classroom practices applied to the teaching of French.

\section{Method}

This research endeavor utilized a combination of different research methodologies. The present study was conducted for one full semester (6 months). The research subjects comprised 37 French Musyawarah Guru Mata Pelajaran (MGMP) instructors in high schools throughout the Jabodetabek region. The research subjects were collected in a WhatsApp group labeled MGMP Prancis Jabodetabek. The group comprised 86 French teachers, 37 of whom were high school instructors while the rest were teachers in elementary and vocational schools. MGMP French High School teachers were selected as research subjects because of the diminished position and emphasis accorded to French as a foreign language specialization/subject option in high school in the 2013 curriculum. The researchers desired to identify the number of teachers who evinced a passion for teaching French at the school level.

The study was designed in the following manner. Teachers who were ascertained to exhibit a passion for their work would be asked to reflect on their classroom pedagogic practices in teaching. To apply the concept of triangulation, a questionnaire regarding the evaluation of learning would also be administered to 34 students in each school. Thus, an aggregate of 204 students from six different schools would also participate in this study. The obtained results would be compared to the outcomes of three randomly selected teachers who exhibited extremely low scores in the category of passion category to determine if any significant differences could be found between the two groups. Further, the teachers would be interviewed to discern factors that influenced their passion for teaching.

Kyriacou and Benmansour's [5] questionnaire on motivation was adapted to distinguish teachers who were passionate about their work. The results of this questionnaire demonstrated the levels of motivation of the participating French teachers. The percentage of each type of motivation evinced by the teachers was then calculated. Next, three teachers who evinced a high proportion of altruistic and intrinsic motivation and lower levels of extrinsic motivation were selected for further investigation. In addition, as mentioned above, three teachers who exhibited low motivation scores across the categories were also selected for the purpose of a comparative analysis of factors that influenced passion. Subsequently, all participating teachers were given a self-reflection sheet adopted from Richards, et al. [16] to obtain data on their classroom teaching practices. They were asked to tick columns containing pre-established provisions in each category. This data analysis was accomplished by focusing on the number of checks placed in each category. A questionnaire from Jannah [13] was also 
administered to around 34 students in each school to obtain data on the student evaluations of the French learning process. This questionnaire intended to determine the effectiveness of classroom learning and the inclusion of the students' point of view was also necessary to complete the method of triangulation. The results of this evaluation questionnaire were utilized to effect the comparative assessment of the two groups of teachers. The independent samples t-test was employed to ascertain whether or not there were significant differences between the two groups. Finally, the data on factors that influence passion were collected through semi-structured interviews and were analyzed through selective coding

Table 1: Profile of French Language Teachers in High Schools throughout Jabodetabek

\begin{tabular}{|c|c|c|c|c|c|}
\hline No. & Initial & $\begin{array}{l}\text { School } \\
\text { Origin }\end{array}$ & $\begin{array}{c}\text { Teaching } \\
\text { experience }\end{array}$ & $\begin{array}{l}\text { Classes } \\
\text { taught }\end{array}$ & $\begin{array}{c}\text { Expertise } \\
\text { level }\end{array}$ \\
\hline 1 & DA & Jakarta & $\begin{array}{l}\text { More than } 5 \\
\text { years }\end{array}$ & $X, X I$ & B1 \\
\hline 2 & IN & Jakarta & $\begin{array}{l}\text { More than } 5 \\
\text { years }\end{array}$ & XI, XII & B1 \\
\hline 3 & AAEW & Jakarta & $\begin{array}{l}\text { More than } 5 \\
\text { years }\end{array}$ & $\begin{array}{l}\text { X, XI, } \\
\text { XII }\end{array}$ & $\mathrm{A} 2$ \\
\hline 4 & SI & Jakarta & $\begin{array}{l}\text { More than } 5 \\
\text { years }\end{array}$ & $X, X I$ & $\mathrm{~A} 1$ \\
\hline 5 & $\mathrm{R}$ & Jakarta & $\begin{array}{l}\text { More than } 5 \\
\text { years }\end{array}$ & $x$ & B1 \\
\hline 6 & TS & Jakarta & $\begin{array}{l}\text { More than } 5 \\
\text { years }\end{array}$ & X, XII & B1 \\
\hline 7 & RKD & Jakarta & $1-2$ years & $\begin{array}{l}\text { X, XI, } \\
\text { XII }\end{array}$ & B2 \\
\hline 8 & $\mathrm{TR}$ & Jakarta & $\begin{array}{l}\text { More than } 5 \\
\text { years }\end{array}$ & $x$ & $\mathrm{~A} 2$ \\
\hline 9 & RB & Jakarta & $\begin{array}{l}\text { More than } 5 \\
\text { years }\end{array}$ & $\begin{array}{l}\text { X, XI, } \\
\text { XII }\end{array}$ & B1 \\
\hline 10 & SW & Jakarta & $1-2$ years & $\mathrm{XI}$ & B2 \\
\hline 11 & $\mathrm{NI}$ & Jakarta & $3-5$ years & $\begin{array}{l}\mathrm{X}, \mathrm{XI}, \\
\mathrm{XII}\end{array}$ & $A 2, B 2$ \\
\hline 12 & YA & Jakarta & $\begin{array}{l}\text { More than } 5 \\
\text { years }\end{array}$ & XI, XII & B1 \\
\hline 13 & $\mathrm{KSH}$ & Jakarta & $\begin{array}{l}\text { More than } 5 \\
\text { years }\end{array}$ & $\begin{array}{l}\text { X, XI, } \\
\text { XII } \\
\end{array}$ & B1 \\
\hline 14 & $A R$ & Jakarta & $1-2$ years & $X, X I$ & B2 \\
\hline 15 & RI & Jakarta & $\begin{array}{l}\text { More than } 5 \\
\text { years }\end{array}$ & XI, XII & B1 \\
\hline 16 & PW & Bekasi & $1-2$ years & $\begin{array}{l}\text { X, XI, } \\
\text { XII }\end{array}$ & $\begin{array}{l}\text { Not } \\
\text { Available }\end{array}$ \\
\hline 17 & TW & Jakarta & $\begin{array}{l}\text { More than } 5 \\
\text { years }\end{array}$ & XI, XII & $\begin{array}{l}\text { Not } \\
\text { Available }\end{array}$ \\
\hline 18 & $A B$ & Jakarta & $1-2$ years & $x$ & $\begin{array}{l}\text { Not } \\
\text { Available }\end{array}$ \\
\hline 19 & AS & Jakarta & $\begin{array}{l}\text { More than } 5 \\
\text { years }\end{array}$ & $X, X I$ & $\begin{array}{l}\text { Not } \\
\text { Available }\end{array}$ \\
\hline 20 & $S$ & Jakarta & $\begin{array}{l}\text { More than } 5 \\
\text { years }\end{array}$ & $\begin{array}{l}\text { X, XI, } \\
\text { XII }\end{array}$ & $\begin{array}{l}\text { Not } \\
\text { Available }\end{array}$ \\
\hline 21 & IN & Jakarta & $\begin{array}{l}\text { More than } 5 \\
\text { years }\end{array}$ & $\begin{array}{l}\text { X, XI, } \\
\text { XII }\end{array}$ & B2 \\
\hline 22 & $M$ & Jakarta & $\begin{array}{l}\text { More than } 5 \\
\text { years }\end{array}$ & $x$ & $\begin{array}{l}\text { Not } \\
\text { Available }\end{array}$ \\
\hline 23 & $A R$ & Jakarta & $\begin{array}{l}\text { More than } 5 \\
\text { years }\end{array}$ & $\begin{array}{l}\mathrm{X}, \mathrm{XI}, \\
\mathrm{XII}\end{array}$ & $\begin{array}{l}\text { Not } \\
\text { Available }\end{array}$ \\
\hline 24 & GN & Jakarta & $\begin{array}{l}\text { More than } 5 \\
\text { years }\end{array}$ & XI, XII & $\mathrm{A} 1$ \\
\hline 25 & IS & Bogor & $\begin{array}{l}\text { More than } 5 \\
\text { years }\end{array}$ & $X, X I$ & $\begin{array}{l}\text { Not } \\
\text { Available }\end{array}$ \\
\hline 26 & SK & Jakarta & $3-5$ years & $\begin{array}{l}\text { X, XI, } \\
\text { XII } \\
\end{array}$ & $A 2, B 2$ \\
\hline
\end{tabular}

\begin{tabular}{|c|c|c|c|c|c|}
\hline 27 & ARH & Bogor & $\begin{array}{l}\text { More than } 5 \\
\text { years }\end{array}$ & $\begin{array}{l}\text { X, XI, } \\
\text { XII }\end{array}$ & $A 2, B 1$ \\
\hline 28 & SBA & Bekasi & $\begin{array}{l}\text { More than } 5 \\
\text { years }\end{array}$ & $\begin{array}{l}\text { X, XI, } \\
\text { XII }\end{array}$ & B2 \\
\hline 29 & SD & Jakarta & $1-2$ years & $\begin{array}{l}\text { X, XI, } \\
\text { XII } \\
\end{array}$ & B2 \\
\hline 30 & $\mathrm{NRH}$ & Bogor & $\begin{array}{l}\text { More than } 5 \\
\text { years }\end{array}$ & $\begin{array}{l}\text { X, XI, } \\
\text { XII }\end{array}$ & B1 \\
\hline 31 & LFS & Jakarta & $\begin{array}{l}\text { More than } 5 \\
\text { years }\end{array}$ & $\begin{array}{l}\mathrm{X}, \mathrm{XI}, \\
\mathrm{XII}\end{array}$ & $\begin{array}{l}\mathrm{A} 1, \mathrm{~A} 2, \\
\mathrm{~B} 1\end{array}$ \\
\hline 32 & ISA & Jakarta & $\begin{array}{l}\text { More than } 5 \\
\text { years }\end{array}$ & XI, XII & B1 \\
\hline 33 & SP & Banten & $\begin{array}{l}\text { More than } 5 \\
\text { years }\end{array}$ & $\begin{array}{l}\text { X, XI, } \\
\text { XII }\end{array}$ & B2 \\
\hline 34 & A & Jakarta & $\begin{array}{l}\text { Less than } 1 \\
\text { year }\end{array}$ & $\begin{array}{l}\text { X, XI, } \\
\text { XII }\end{array}$ & $A 2, B 1$ \\
\hline 35 & NW & Tangerang & $1-2$ years & $X, X I$ & $\mathrm{~A} 1, \mathrm{~A} 2$ \\
\hline 36 & Wen & Jakarta & $\begin{array}{l}\text { More than } 5 \\
\text { years }\end{array}$ & X, XII & $\mathrm{A} 1, \mathrm{~A} 2$ \\
\hline 37 & NK & Bekasi & $\begin{array}{l}\text { More than } 5 \\
\text { years }\end{array}$ & $\begin{array}{l}X, X I, \\
X I I\end{array}$ & $\begin{array}{l}\text { Not } \\
\text { Available }\end{array}$ \\
\hline
\end{tabular}

\section{Results and Discussion}

The passion for teaching can be identified through the examination of the quality of each of the three motivational categories described earlier in the paper. If teachers demonstrate high altruistic and intrinsic motivation and at the same time, their extrinsic motivation is on the lower side, they may be said to evince passion for their work. However, if the extrinsic motivation of teachers is high, they cannot be included in the category of educators who are passionate about their profession.

For the present study, the distribution of quality was determined based on the percentage calculated for each type of motivation. A percentage of $0 \%-25 \%$ implied low motivation levels, $26 \%-50 \%$ signified that the teacher's motivation was quite low, $51 \%-75 \%$ indicated high motivation, and 76\%-100\% represented extremely high motivation for teaching. Table 2 presents the results of the analysis of questionnaire data pertaining to the participants' self-reported passion for teaching.

Table 2: Passion for Teaching Demonstrated by French Teachers in High Schools throughout Jabodetabek

\begin{tabular}{|c|c|c|c|c|c|c|c|c|c|}
\hline $\begin{array}{l}\text { Res } \\
\text { pon } \\
\text { dent } \\
(\mathrm{N}= \\
37)\end{array}$ & $\begin{array}{l}\text { Ite } \\
\mathrm{ms}\end{array}$ & $\begin{array}{c}\text { Perc } \\
\text { enta } \\
\text { ge }\end{array}$ & $\begin{array}{l}\mathrm{Qu} \\
\text { alit } \\
\mathrm{y}\end{array}$ & $\begin{array}{l}\text { Pass } \\
\text { ion } \\
\text { for } \\
\text { Teac } \\
\text { hing }\end{array}$ & $\begin{array}{c}\text { Resp } \\
\text { onde } \\
n t \\
(\mathrm{~N}= \\
37)\end{array}$ & $\begin{array}{c}\text { Item } \\
\mathrm{s}\end{array}$ & $\begin{array}{c}\text { Perc } \\
\text { enta } \\
\text { ge }\end{array}$ & $\begin{array}{c}\text { Qu } \\
\text { alit } \\
y\end{array}$ & $\begin{array}{c}\text { Passi } \\
\text { on for } \\
\text { Teac } \\
\text { hing }\end{array}$ \\
\hline \multirow[t]{3}{*}{$\mathrm{DA}$} & $\begin{array}{c}\text { Alt } \\
\text { ruis } \\
\text { tic }\end{array}$ & 95 & $\begin{array}{l}\mathrm{Hi} \\
\text { gh }\end{array}$ & No & RI & $\begin{array}{c}\text { Altr } \\
\text { uisti } \\
\mathrm{c}\end{array}$ & 85 & $\begin{array}{c}\mathrm{Hig} \\
\mathrm{h}\end{array}$ & Close \\
\hline & $\begin{array}{c}\text { Intr } \\
\text { insi } \\
c\end{array}$ & 76 & $\begin{array}{l}\mathrm{Hi} \\
\mathrm{gh}\end{array}$ & & & $\begin{array}{l}\text { Intri } \\
\text { nsic }\end{array}$ & 93 & $\underset{\mathrm{h}}{\mathrm{Hig}}$ & \\
\hline & $\begin{array}{c}\text { Ext } \\
\text { rins } \\
\text { ic }\end{array}$ & 84 & $\begin{array}{l}\mathrm{Hi} \\
\text { gh }\end{array}$ & & & $\begin{array}{c}\text { Extri } \\
\text { nsic }\end{array}$ & 72 & $\begin{array}{c}\text { Qui } \\
\text { te } \\
\text { Hig } \\
\text { h }\end{array}$ & \\
\hline \multirow[t]{2}{*}{ NI } & $\begin{array}{c}\text { Alt } \\
\text { ruis } \\
\text { tic }\end{array}$ & 90 & $\begin{array}{l}\mathrm{Hi} \\
\mathrm{gh}\end{array}$ & $\begin{array}{c}\text { Clos } \\
\mathrm{e}\end{array}$ & $\begin{array}{l}\mathrm{NU} \\
\mathrm{RH}\end{array}$ & $\begin{array}{c}\text { Altr } \\
\text { uisti } \\
\mathrm{c}\end{array}$ & 75 & $\begin{array}{c}\text { Qui } \\
\text { te } \\
\text { Hig } \\
\text { h }\end{array}$ & No \\
\hline & $\begin{array}{c}\text { Intr } \\
\text { insi } \\
c\end{array}$ & 86 & $\begin{array}{l}\mathrm{Hi} \\
\mathrm{gh}\end{array}$ & & & $\begin{array}{l}\text { Intri } \\
\text { nsic }\end{array}$ & 71 & $\begin{array}{l}\text { Qui } \\
\text { te } \\
\text { Hig } \\
\text { h }\end{array}$ & \\
\hline
\end{tabular}




\begin{tabular}{|c|c|c|c|c|c|c|c|c|c|}
\hline \multirow{4}{*}{$\begin{array}{c}\mathrm{KS} \\
\mathrm{H}\end{array}$} & $\begin{array}{c}\text { Ext } \\
\text { rins } \\
\text { ic }\end{array}$ & 75 & $\begin{array}{l}\text { Qu } \\
\text { ite } \\
\mathrm{Hi} \\
\text { gh }\end{array}$ & & & $\begin{array}{c}\text { Extri } \\
\text { nsic }\end{array}$ & 78 & $\begin{array}{c}\mathrm{Hig} \\
\mathrm{h}\end{array}$ & \multirow{4}{*}{ Close } \\
\hline & $\begin{array}{c}\text { Alt } \\
\text { ruis } \\
\text { tic }\end{array}$ & 90 & $\begin{array}{l}\mathrm{Hi} \\
\mathrm{gh}\end{array}$ & No & ISA & $\begin{array}{c}\text { Altr } \\
\text { uisti } \\
\text { c }\end{array}$ & 85 & $\begin{array}{c}\mathrm{Hig} \\
\mathrm{h}\end{array}$ & \\
\hline & $\begin{array}{c}\text { Intr } \\
\text { insi } \\
\text { c }\end{array}$ & 89 & $\begin{array}{l}\mathrm{Hi} \\
\mathrm{gh}\end{array}$ & & & $\begin{array}{l}\text { Intri } \\
\text { nsic }\end{array}$ & 82 & $\begin{array}{c}\mathrm{Hig} \\
\mathrm{h}\end{array}$ & \\
\hline & $\begin{array}{c}\text { Ext } \\
\text { rins } \\
\text { ic }\end{array}$ & 88 & $\begin{array}{l}\mathrm{Hi} \\
\mathrm{gh}\end{array}$ & & & $\begin{array}{l}\text { Extri } \\
\text { nsic }\end{array}$ & 66 & $\begin{array}{c}\text { Qui } \\
\text { te } \\
\text { Hig } \\
\text { h }\end{array}$ & \\
\hline
\end{tabular}

As Table 2 illustrates, none of the teachers reported levels of extrinsic motivation that were "quite low" or "low." In other words, none of the high school French teachers can be adjudged to evince a passion for teaching, proving that the French teachers in high schools throughout Jabodetabek prioritize elements extrinsic to their actual task of imparting learning. The findings also support Rampa's [9] assertion that passionate teachers are more easily discoverable in the 3T regional schools or elite educational institutions. Even so, three teachers were identified as approaching the desired levels of passion for teaching (NI, RI, and ISA in Table 1), namely those who exhibited high levels of intrinsic or altruistic motivation. In addition, three teachers who scored extremely low in all categories of motivation (DA, KSH, and NURH in Table 1) were chosen for the comparative analysis of factors influencing passion. Serin [2] contended that if the teaching and learning effectiveness emanated from passion, would teachers who are close to passionate or those who are not at all passionate be completely unable to produce effective learning or be evaluated as effective by students? The three teachers (NI, RI, and ISA) who were close to approaching the desired levels of passion for teaching were expected to demonstrate satisfactory teaching abilities akin to teachers who are truly passionate about their profession. To prove this estimation, it was necessary to collect data on their actual pedagogic practices and the manner in which students evaluated them. Student evaluation was selected as an appropriate measure because it is correlated to the teacher's passion for imparting learning. It has been established that passionate teachers receive positive evaluations from their students [1]. The analysis of the self-reflection sheets revealed that most teachers believed that they executed the aspects of effective language teaching with the following frequency (Table 3).

Table 3: Teachers' Self-Reflection Scores of the Aspects of Effective Language Teaching

\begin{tabular}{|c|c|c|c|c|c|c|}
\hline \multirow{2}{*}{$\begin{array}{l}\text { Teaching } \\
\text { Aspects }\end{array}$} & \multicolumn{6}{|c|}{ Teachers' Initial } \\
\hline & $N I$ & $R I$ & ISA & $D A$ & KSH & $N U R H$ \\
\hline $\begin{array}{l}\text { Access and } \\
\text { use target } \\
\text { language } \\
\text { sources } \\
\text { (textbooks, } \\
\text { internet, } \\
\text { newspapers, } \\
\text { etc.) }\end{array}$ & (다)(ㄴ) (ㄱ) & (다)(ㄴ) (ㄷ) & (간(1) (1) & (다) (1) & (다)(1) & (ㄱ) (1) (1) \\
\hline $\begin{array}{l}\text { Use } \\
\text { vocabulary } \\
\text { in the target }\end{array}$ & (다)(난) & (ㄴ)(ㄴ) & 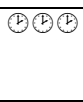 & (다(1) & (ㄴ)(ㄴ)(ㄴ) & (가 (ㄱ) (1) \\
\hline
\end{tabular}

\begin{tabular}{|c|c|c|c|c|c|c|}
\hline $\begin{array}{l}\text { language } \\
\text { correctly }\end{array}$ & & & & & & \\
\hline $\begin{array}{l}\text { Use } \\
\text { structure in } \\
\text { the target } \\
\text { language } \\
\text { correctly }\end{array}$ & (ㄷ)(ㄴ) & (ㄴ)(ㄴ) & (ㄴ)() (2) & (1) (1) & (D)(D) (D) & (1) (1) \\
\hline $\begin{array}{l}\text { Use } \\
\text { everyday } \\
\text { language } \\
\text { that is } \\
\text { easily } \\
\text { understood } \\
\text { in the target } \\
\text { language } \\
\text { correctly }\end{array}$ & (ㄷ) (b) (5) & (D) (D) (D) & (ㄴ)(ㄴ) & (1) (1) & () (1) (D) & (ㄴ)(1) \\
\hline $\begin{array}{l}\text { Provide } \\
\text { corrective } \\
\text { feedback on } \\
\text { appropriate } \\
\text { student's } \\
\text { errors }\end{array}$ & (1) (1) (D) & (ㄴ)(ㄴ) & (ㄴ) (b) (1) & (2) (2) (2) & (D) (L) (L) & (1) \\
\hline $\begin{array}{l}\text { Use the } \\
\text { target } \\
\text { language to } \\
\text { provide } \\
\text { instructions } \\
\text { (direction) } \\
\text { in } \\
\text { managing } \\
\text { the class }\end{array}$ & (ㄴ) (b) (1) & (D) (D) (D) & (1)(ㄴ) & (1)(1) & (ㄴ)(1) & (ㄴ)(ㄴ) \\
\hline $\begin{array}{l}\text { Provides an } \\
\text { explanation } \\
\text { of the target } \\
\text { language's } \\
\text { vocabulary } \\
\text { correctly }\end{array}$ & (ㄴ) (1) (1) & (1) (1) & (ㄴ)(b) (D) & (1) (1) & (1)(1) & (ㄴ)(ㄴ) \\
\hline $\begin{array}{l}\text { Provide a } \\
\text { precise } \\
\text { explanation } \\
\text { of the } \\
\text { structure of } \\
\text { the target } \\
\text { language }\end{array}$ & (ㄴ)(ㄴ) & (ㄴ)(ㄴ) & (ㄴ)(ㄴ) (D) & (1) (1) & (ㄴ)(ㄴ) & (ㄴ)(ㄴ) \\
\hline $\begin{array}{l}\text { Appropriate } \\
\text { speed }\end{array}$ & & (D) (D) (D) & (1) (1) & (1) (1) & (ㄴ)(ㄴ) (D) & (ㄴ)(1) \\
\hline $\begin{array}{l}\text { Repetition } \\
\text { in giving } \\
\text { instructions }\end{array}$ & (ㄴ) (1) (1) & (ㄷ)(1) & (ㄴ)(ㄴ) (2) & (ㄴ) (1) (1) & (ㄱ) (D) (D) & (ㄷ)(1) (1) \\
\hline $\begin{array}{l}\text { Long } \\
\text { speech }\end{array}$ & & (1) & (1) & (5) & (1) & (ㄴ) \\
\hline $\begin{array}{l}\text { Sentences } \\
\text { with the } \\
\text { right level } \\
\text { of difficulty }\end{array}$ & (1) (1) & () & (1)(1) & (1)(1) & (ㄴ)(ㄴ) & (1) \\
\hline Use humor & (2) & (ㄴ)(강 & (ㄴ)(ㄱ) (ㄴ) & (ㄷ) & (ㄱ) (ㄱ) (ㄴ) & (ㄴ) \\
\hline $\begin{array}{l}\text { Improvise } \\
\text { in teaching }\end{array}$ & (1) (1) & (ㄷ) (ㄴ) (1) & (ㄱ) () () & (ㄷ)(ㄱ) & (ㄱ) (1) & (ㄴ)(1) \\
\hline
\end{tabular}

The data presented in Table 3 lead to the conclusion that all the participating teachers consistently practice the majority of the desired categories of language instruction. Even so, one category was university accorded a single checkmark, which indicated "sometimes." The interviews revealed that the teachers assumed that high school students were not able to 
understand long speeches in French. Thus, they were inclined to shorten sentences to make them simpler and thus more easily understood by the learners. If teachers believe they perform all the desired language learning criteria posited by Naserdeen [14] and Richards, et al. [16], they should be effective in their teaching. However, all the six teachers identified for the comparative analysis received unfavorable assessments and were evaluated as unsatisfactory by their students as is shown in Table 4.

Table 4: Average Teacher and Learning Quality Evaluation

\begin{tabular}{|l|l|l|l|}
\hline \multicolumn{1}{|c|}{ Group } & Initial & $\begin{array}{c}\text { Student } \\
\text { Evaluation Mean }\end{array}$ & \multicolumn{1}{c|}{$\begin{array}{c}\text { Teaching } \\
\text { Quality }\end{array}$} \\
\cline { 1 - 3 } Close to the desired & NI & 59,11 & Quite Good \\
passion & RI & 55,55 & Quite Bad \\
classification & ISA & 56,29 & Quite Bad \\
\cline { 1 - 3 } Far from the desired & DA & 58,38 & Adequate \\
passion & KSH & 57,32 & Adequate \\
classification & NURH & 56,32 & Quite Bad \\
\hline
\end{tabular}

The results of the analysis of the student evaluations of the effectiveness of classroom learning imparted by the two groups of teachers to be compared disclose that the practiced language teaching criteria and student evaluations are not aligned. Of the three teachers categorized as approaching the desired passion for teaching, two (RI and ISA) were rated "quite bad" from their students, while only one (NI) was scored as "quite good." Approximately the same outcomes were computed for the three teachers who scored extremely low in the passion evaluation. Two teachers in this group (DA and $\mathrm{KSH}$ ) received a rating of "adequate" and one (NURH) was evaluated as "quite bad." Thus, the teachers' own assessment of their fulfillment of all the language learning criteria and their self-belief that their teaching was effective were not corroborated by their students' assessments of their abilities. In fact, the association between the self-reporting of teaching aspects and student evaluations may be said to be contradictory. Of the six evaluated teachers, only one (NI) evinced a positive relationship. These findings confirm that to be truly effective, teachers must exhibit a true passion for their profession. In fact, even if teachers view their pedagogy to be effective, students are not likely to find their performance very satisfactory.

As the final step of the investigation, an independent t-test was conducted via SPSS to determine whether any significant differences could be found between the two identified groups of almost passionate and not passionate teachers. The two groups were also tested prior to the t-test and were found to demonstrate a normal and homogeneous distribution. The results of the free sample test did not demonstrate any significant difference because the sig value (2-tailed) of 0.787 was greater than 0.05 . Thus, both groups of teachers may be said to equally produce learning that is less satisfying for their students. The calculation of differences is presented in Table 5 .

Table 5: Independent Samples Test

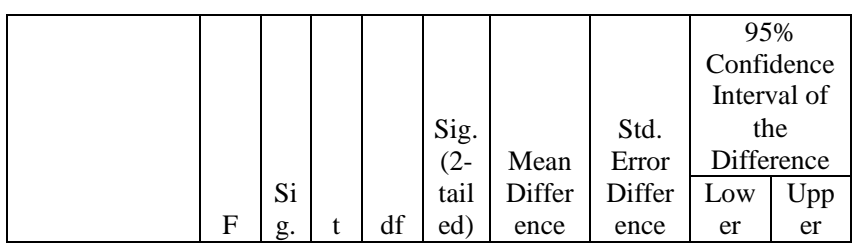

\begin{tabular}{|c|c|r|r|r|r|r|r|r|r|r|}
\hline Teach & Equal & 1.8 & .2 & - & 4 & .78 & - & 1.2369 & - & 3.07 \\
er & varia & 44 & 46 & .2 & & 7 & .35667 & 5 & 3.79 & 766 \\
Evalua & nces & & & 88 & & & & & 099 & \\
tion & $\begin{array}{c}\text { assu } \\
\text { Avera }\end{array}$ & & & & & & & & \\
med & & & & & & & & & \\
\cline { 2 - 8 } & Equal & & & -3.1 & .79 & - & 1.2369 & - & 3.50 \\
& varia & & & 03 & 1 & .35667 & 5 & 4.22 & 689 \\
& nces & & & 88 & & & & & 022 & \\
& not & & & & & & & & & \\
& assu & & & & & & & & & \\
\hline
\end{tabular}

Therefore, teachers, schools, and educational institutions must nurture, develop, and maintain the passion for teaching in their teachers. The imparting of learning is essentially an activity that arises from a call from the heart. Without passion, teachers cannot create effective learning in their students, as has been evidenced from the two groups compared in the above analyses. Certain internal and external factors must be taken into account in nurturing and sustaining the attribute of passion in teachers. The results of the analysis of the data obtained from the semi-structured interviews with the selected teachers revealed the following facets. A positive outlook about work, the age of the teachers, clear teaching goals, and a love for the material are categorized as internal factors that influenced the passion for teaching. On the other hand, educational backgrounds, attitudes, and motivations of teachers, facilities, fellow teachers, community practice, inspirational learning figures, and the novelty of teaching materials were classified as the external factors that could affect passion in teachers. These features should be accorded great significance by the teachers themselves, by their educational institutions, and by schools preparing curricula designed to foster a passion for teaching to current or prospective teachers of French. If the passion of teachers can be cultivated and perpetuated, the learning of French will become fun for students and will advance. Unfortunately, the present study was unable to identify a single French teacher in high schools throughout Jabodetabek who could be deemed passionate. The researchers were therefore compelled to consider samples that came close to being categorized as being passionate for the comparative aspects of the analysis. For subsequent studies, research on passion should be conducted in 3T areas or in elite schools following Rampa's [9] claim that it is easier to find teachers with passion in such places. Prospective research projects could also focus on ways of inculcating and strengthening passion in teachers, both through the design of appropriate professional development programs and through integrated curricula that highlight the development of soft skills such as passion.

\section{Conclusion}

The results of this study may be applied to all fields of study, and not merely to French instruction because passion is a foundational quality for all those engaged in the profession of imparting education. All teachers must be passionate about their work to be effective. Unfortunately, teachers who are not passionate or even those who approach passion without actually achieving it have been proven unable to accomplish effective learning outcomes. This study has unequivocally found that effective learning evaluations from students cannot be attained unless teachers can convey true passion for their profession. There is, therefore, a dire need for teachers who are really passionate, but it is not easy to find such 
professionals in the current environment. However, as most students will vouch, passionate teachers do exist. These special teachers are unusual: they strive and work earnestly to generate the next golden generation. They provide inspirations and solutions. Everything they do is an example for all students. They embody the truth that education, knowledge, and care must be continuously ameliorated. Profit cannot be the only motive for teaching and learning because external elements are ephemeral and ever-changing. However, knowledge and care last forever. Therefore, the passion for teaching in teachers must assiduously be cultivated and maintained.

\section{Acknowledgments}

I would like to express my deep gratitude to Sisilia Setiawati Halimi, S.S., M.A., Ph.D., my research supervisor, for her patient guidance, encouragement, and useful critique of this study. I would also like to thank MGMP Bahasa Prancis Jabodetabek, community of practice, for their support and for enabling my visits to their schools to collect the plant data. Finally, I wish to thank my wife and my parents for their support and encouragement throughout my research endeavors. This research project is funded by PITMA Grant no. NKB-0991/UN2.R3.1/HKP.05.00/2019 from Universitas Indonesia

\section{References}

[1] Day, C. (2004). Passion for teaching. New York: Routledge.

[2] Serin, H. (2017). The role of passion in learning and teaching. International Journal of Social Sciences \& Educational Studies, 4(1), 60-64. DOI: 10.23918/ijsses.v4i1p60.

[3] Hargreaves, A. (1997). Rethinking educational change with heart and mind. Alexandria, VA: Association for Supervision and Curriculum Development.

[4] Soltis, J. F. (1973). The passion to teach. Theory into Practice, 12(1), 5-12. DOI: 10.1080/00405847309542423.

[5] Kyriacou, C., \& Benmansour, N. (1999). Motivation to become a teacher of a foreign language. Language Learning Journal, 19(1), $69-72$.
[6] Dornyei, Z. (2018). Motivating students and teachers. In Liontas, J. I. (Ed.), The TESOL encyclopedia of English language teaching (Vol. 7; pp. 4293-4299). Alexandria, VA: TESOL.

[7] Dewaele, J.-M. (2018). The relationship between trait emotional intelligence and experienced ESL/EFL teachers' love of english, attitudes towards their students and institution, self-reported classroom practices, enjoyment and creativity. Chinese Journal of Applied Linguistics, 4(4), 468-487.

[8] Barnes, A. (2005). A passion for languages: motivation and preparation to teach modern foreign languages in eight cohorts of beginning teachers. Research Paper in Education, 20(4), 349-369.

[9] Rampa, S. H. (2012). Passion for teaching: a qualitative study. Procedia-Social and Behavioral Sciences, 47, 1281-1285. DOI: 10.1016/j.sbspro.2012.06.812.

[10] Slavin, R. E. (2009). Psikologi pendidikan: teori dan praktik (Edisi ke8 Jilid 2). Jakarta: PT Indeks.

[11] Suprayekti. (2003). Interaksi belajar mengajar. Jakarta: Departemen Pendidikan Nasional.

[12] Kunandar. (2011). Guru profesional implementasi kurikulum tingkat satuan pendidikan dan sukses dalam sertifikasi pembelajar. Jakarta: PT Rajagrafindo Persada.

[13] Jannah, Z. N. (2016). Pengaruh efektifitas guru dalam mengajar terhadap hasil belajar siswa pada mata pelajaran agama Islam siswa kelas X SMAN 1 Batur Banjarnegara. Yogyakarta: UMY. Skripsi nonpublikasi.

[14] Naserdeen, D. (2001). Second language study in elementary school. Multicultural Education, 8(3), 21-23.

[15] Farrell, T. S., \& Richards, J. (2007). Teachers' language proficiency. In T. S. Farrell (ed.), Reflective language teaching: from research to practice (pp. 55-66). London: Continuum.

[16] Richards, H., Conway, C., Roskvist, A., \& Harvey, S. (2013). Foreign language teachers' language proficiency and their language teaching practice. The Language Learning Journal, 41(2), 231-246. DOI: 10.1080/09571736.2012.707676.

[17] Lustyantie, N. (2014). Kedudukan mata pelajaran bahasa Prancis dalam kurikulum 2013. Prosiding dari Seminar Nasional Bahasa (Indonesia, Asing, Daerah) dan Sastra dalam Kurikulum 2013. Jakarta: UNJ.

[18] Mamengko, R. P. (2011). Efektivitas penerapan metode quantum learning dalam proses pembelajaran keterampilan menulis bahasa Prancis siswa kelas XI IPA SMA Negeri 1 Prambanan Klaten tahun ajaran 2010/2011. Yogyakarta: UNY. Skripsi nonpublikasi. 